\section{Formation of Compact Pieces of Grey Tin}

IN a previous communication ${ }^{1}$ the formation of compact pieces of grey tin was announced. A spectrophotometrical analysis of the material used indicated the presence of mercury, a metal which does not occur in natural tin. Consequently, the presence of mercury must be responsible for the behaviour of this specific material. This fact led to an investigation of the properties of tin-mercury alloys.

According to the literature ${ }^{2}$, addition of more than 2 atomic per cent mercury forms a two-phase system, the phases being tetragonal and hexagonal, the composition of this latter being given as $\mathrm{HgSn}_{12}$. At 8 atomic per cent mercury, the tetragonal phase disappears.

We prepared tin-mercury alloys, in the range 0.03-6 atomic per cent mercury, by melting in vacuum. X-ray photographs, taken after annealing, showed the presence of the hexagonal phase already in alloys with more than about 0.2 atomic per cent mercury, that is, at much lower mercury contents than given in ref. 2.

All amalgams showed at $-20^{\circ} \mathrm{C}$. an increased rate of transition as compared with that of pure tin (Johnson-Matthey). Above $\mathbf{0 . 2}$ atomic per cent mercury the grey tin formed is compact. X-ray photographs showed that the tetragonal tin phase is transformed into the cubic grey modification, whereas the hexagonal phase is still present after the transition in the two-phase system. It might be suggested that the hexagonal phase acts as a matrix, holding the particles of the grey tin together ; but microscopical studies have provided so far no evidence in favour of this suggestion.

The presence of a few tenths per cent of mercury increased also the rate of transition of other samples of tin, among them commercial grade tin and even samples of tin containing a small quantity of lead, for example, 0.03 per cent, or 0.1 per cent bismuth. This latter is the more remarkable as these two metals themselves decrease the rate of transition. In all these cases compact pieces of grey tin were formed. Pieces measuring several centimetres in length and about $0.5 \mathrm{~cm}$. thick were obtained in this way.

Laboratory of Physical Chemistry,

L. J. GROEN

Technical University,

Delft. July 20.

1 Groen, L. J., and Burgers, W. G., Proc. Kon. Akad. Wet. Amsterdam, B, 57, 79 (1954).

- References in "Equilibrium Data for Tin-Alloys" (Tin Research Institute, 1949).

\section{External Metasomatism associated with Serpentine}

AFTer finding in Turkey that many geosynclinal serpentines appear to be submarine lava flows ${ }^{1}$, we re-examined in Ayrshire the only known exposure of an actual contact between the Ballantrae serpentine and associated spilites. The evidence is difficult to disentangle, but it proved beyond doubt that the serpentine is earlier than the particular spilite concerned $^{2}$, not vice versa as had previously been sup. posed. Full publication has been delayed. Here we only wish to emphasize that the spilite, though the later of the two rocks, is strikingly altered for a distance of some few inches in from the contact, and that it is penetrated by some minute veins of ser- pentinous material, some of which also clearly cut the serpentine itself. Away from the contract the spilite is an olive-green rock, dappled with very pale grey, or whitish, felspars. In its altered border-zone, which has an almost abrupt boundary, it turns reddish, sometimes purplish, with areas that are much paler ; and its felspars are completely pseudomorphed by dark green translucent material that appears darker, instead of paler, than the matrix.

Under the microscope, the red coloration of the altered base is seen to be due to a close precipitation of iron ore powder. The paler areas are rich in leucoxene. The pseudomorphed felspars are replaced by some mineral of the chlorite-serpentine category, which also seems to furnish the main constituent of the base.

One important conclusion which we drew was that the parent peridotite of the serpentine still contained fresh olivine when the spilite came into contact with it, for serpentinization of olivine seems to us the only possible source of the magnesian solutions responsible for the alteration of the spilite. Analogies with the development of white trap and of spilite itself are sufficiently obvious. The interest of the occurrence has been greatly enhanced by two subsequent descriptions of almost identical alteration in France. Vuagnat ${ }^{3}$ has described the phenomenon in a spilitic pillow-lava-agglomerate with fragmental serpentine matrix in the Montgenèvre district of the High Alps, $180 \mathrm{~km}$. south-south-east of Geneva; and Vuagnat and Jaffé ${ }^{4}$ in a "conglomerate", as they call it, contrining many spilitic fragments in a "sorte de purée de serpentine", $2 \mathrm{~km}$. east-north-east of Gets in the Prealps, $40 \mathrm{~km}$. east from Geneva. These authors are as clear as ourselves that the alteration in the spilitic material is due to interaction with magnesian solutions. As regards the origin of the serpentine of the matrix, they are non-committal. We are, however, assured that some of the frag. ments in the matrix of the Montgenèvre occurrence show the typical mesh-structure of normal serpentine along with the usual bastite plates.

The new work carried out at Geneva is backed by rock analyses. These confirm, what is self-evident, the metasomatic nature of the alteration of the spilitic material. They also demonstrate that the main mineral (or minerals) produced is aluminous, and therefore chlorite rather than serpentine.

19 Greenhill Gardens, Edinburgh.

E. B. BAILEY

University College,

Gold Coast. July 25.

${ }^{1}$ Bailey, E. B., and McCallien, W. J., Nature, 166, 938 (1950); Trans. Roy. Soc. Edin., 62, 403 (1953).

2 Bailey, E. B., and McCallien, W. J., Trans. Edin. Geol. Soc., 15, 14

3 Vuagnat, M., Bull. Soc. frans. Minér. Crist., 76, 438 (1953).

- Vuagnat, M., and Jaffé, F., Arch. Sci. Phys. et Nat., Geneve, 7. 5 (1854).

\section{Measurement of the Refractive Index of Cytoplasmic Inclusions in Living Cells by the Interference Microscope}

A метноD of measuring the refractive index of living cytoplasm by phase-contrast microscopy was recently developed by Dr. R. Barer and his associates ${ }^{1,2}$. This method consisted essentially of suspending cells in an isotonic protein medium of the same refractive index as the cytoplasm, which 